\title{
Point-of-care creatinine measurements to predict acute kidney injury
}

\author{
Vaara, Suvi T.
}

2020-07

Vaara , S T , Glassford , N , Eastwood , G M , Canet , E , Mårtensson , J \& Bellomo , R 2020

, ' Point-of-care creatinine measurements to predict acute kidney injury ', Acta

Anaesthesiologica Scandinavica, vol. 64 , no. 6 , pp. 766-773 . https://doi.org/10.1111/aas.13564

http://hdl.handle.net/10138/326420

https://doi.org/10.1111/aas.13564

unspecified

acceptedVersion

Downloaded from Helda, University of Helsinki institutional repository.

This is an electronic reprint of the original article.

This reprint may differ from the original in pagination and typographic detail.

Please cite the original version. 
DR SUVI VAARA (Orcid ID : 0000-0002-6851-3828)

Article type : Clinical investigation

\section{Point-of-care creatinine measurements to predict acute kidney injury}

Suvi T. Vaara, ${ }^{1,2}$ Neil Glassford, 2,3,4,5 Glenn M. Eastwood, ${ }^{2}$ Emmanuel Canet,, ${ }^{2,6}$ Johan Mårtensson, ${ }^{7}$ Rinaldo Bellomo ${ }^{2}$

${ }^{1}$ Division of Intensive Care Medicine, Department of Anesthesiology, Intensive Care and Pain Medicine, University of Helsinki and Helsinki University Hospital, Helsinki, Finland

${ }^{2}$ Department of Intensive Care, Austin Hospital, Austin Health, Melbourne, Australia

${ }^{3}$ Intensive Care Unit, Royal Melbourne Hospital, Melbourne Health, Melbourne, Australia

${ }^{4}$ Department of Epidemiology and Preventative Medicine, School of Public Health and Preventative Medicine, Monash University, Melbourne, Australia

${ }^{5}$ Centre for Integrated Critical Care, Department of Medicine \& Radiology, Melbourne Medical School, The University of Melbourne, Melbourne, Australia

${ }^{6}$ Intensive Care Unit, Nantes University Hospital; University of Nantes, France

${ }^{7}$ Department of Physiology and Pharmacology, Karolinska Institutet, Stockholm, Sweden

Short title: Point-of care creatinine and AKI

Key words: point-of-care, acute kidney injury, creatinine, prediction, critically ill

Corresponding author: Suvi T. Vaara, staff specialist

Address: Intensive Care Unit M1, Meilahti Hospital, Box 340, 00290 Helsinki, Finland.

Phone +358 503312433 Fax: +358947175678 E-mail: suvi.vaara@helsinki.fi

Word count: manuscript 2797, abstract 234

This article has been accepted for publication and undergone full peer review but has not been through the copyediting, typesetting, pagination and proofreading process, which may lead to differences between this version and the Version of Record. Please cite this article as doi: 10.1111/AAS.13564

This article is protected by copyright. All rights reserved 


\section{Abstract}

Background: Plasma creatinine $(\mathrm{Cr})$ is a marker of kidney function and typically measured once daily. We hypothesized that $\mathrm{Cr}$ measured by point-of-care technology early after ICU admission would be a good predictor of acute kidney injury (AKI) the next day in critically ill patients.

Methods: We conducted a retrospective database audit in a single tertiary ICU database. We included patients with normal first admission $\mathrm{Cr}\left(\mathrm{Cr}_{F}\right)$ and identified a $\mathrm{Cr}$ value $\left(\mathrm{Cr}_{\mathrm{P}}\right)$ obtained within 6 to $12 \mathrm{hrs}$ from ICU admission. We used their difference converted into percentage (delta-Cr-\%) to predict subsequent AKI (based on $\mathrm{Cr}$ and/or need for renal replacement therapy) the next day. We assessed predictive value by calculating area under the receiver characteristic curve $(A \cup C)$, logistic regression models for AKI with and without delta-Cr-\%, and the categoryfree net reclassifying index (cfNRI).

Results: We studied 780 patients. Overall, 70 (9.0\%) fulfilled the $\mathrm{Cr}$ AKI definition by $\mathrm{Cr}_{\mathrm{p}}$ measurement. On day 2, 148 patients (19.0\%) were diagnosed with AKI. AUC (95\% Cl) for deltaCr-\% to predict AKI on day 2 was 0.82 (95\% $\mathrm{Cl} 0.78-0.86)$, and 0.74 (95\% $\mathrm{Cl} 0.69-0.80)$ when patients with AKI based on the $\mathrm{Cr}_{p}$ were excluded. Using a cut-off of $17 \%$ increment, the positive likelihood ratio $(95 \% \mathrm{Cl})$ for delta-Cr-\% to predict AKI was $3.5(2.9-4.2)$. The cfNRI was 90.0 (74.9-106.1).

Conclusions: Among patients admitted with normal $\mathrm{Cr}$, early changes in $\mathrm{Cr}$ help predict $\mathrm{AKI}$ the following day.

\section{Editorial Comment:}

In a single-centre cohort, the measurement of a change in creatinine from admission to 6-12 hours later using point-of-care technology could predict the development of acute kidney injury on the subsequent day based on KDIGO criteria. The potential clinical impact to improve outcomes once having this kind of result in hand needs to be studied.

This article is protected by copyright. All rights reserved 


\section{Introduction}

Approximately 40 to $60 \%$ of intensive care unit (ICU) patients suffer from acute kidney injury (AKI), which is independently associated with an increased risk of mortality. ${ }^{1,2}$ Earlier detection of AKI may allow better management of these patients including, for example, avoidance of further insults to the kidney. Great effort has therefore been put in finding novel biomarkers capable of predicting the development of $\mathrm{AKI}^{3}{ }^{3}{ }^{4}$ However, the performance of most novel biomarkers has been variable in an unselected mixed critically ill population. ${ }^{5}$

Plasma creatinine $(\mathrm{Cr})$ has traditionally been measured only once daily even in the critically ill. ${ }^{6}$ Along with urine output and need for renal replacement therapy (RRT), $\mathrm{Cr}$ is a key diagnostic criterion of the Kidney Diseases: Improving Global Outcomes (KDIGO) definition of AKI. ${ }^{7}$ Consequently, more frequent screening for AKI with point-of-care $\mathrm{Cr}$ measurements could be a useful tool for predicting AKI and diagnosing it earlier. Promising results have been reported among elective cardiac surgery patients using $\mathrm{Cr}$ value obtained 6 hours after surgery. ${ }^{8}$ Moreover, a single center prospective study found small changes in point-of-care $\mathrm{Cr}$ observed very early (3-4 hours from ICU admission) to be sensitive, but non-specific markers of subsequent AKI. ${ }^{9}$ However, the usefulness of point-of-care $\mathrm{Cr}$ measurements obtained 6 hours from ICU admission in AKI prediction among unselected mixed ICU patients has not been studied.

Measurement of $\mathrm{Cr}$ as a part of routine blood-gas analyses as a point-of-care test, was introduced in our ICU in $2011^{10}$ and has been shown to correlate well with central laboratory Cr results. ${ }^{10,11}$ Thus, we performed a retrospective database audit to assess the value of point-ofcare $\mathrm{Cr}$ measurement in predicting AKI (based on $\mathrm{Cr}$ or RRT) on the following day among patients who were admitted to ICU with normal $\mathrm{Cr}$ values. We hypothesized that the difference between the first point-of-care measured $\mathrm{Cr}$ and a subsequent point-of-care measurement at least 6 but no more than 12 hours apart would be a good predictor of patient's AKI status on the following day.

This article is protected by copyright. All rights reserved 


\section{Methods}

Design and setting

This was a retrospective audit in database consisting of adult patients admitted between 1.1.2011 and 31.12.2012 to Austin Hospital ICU providing tertiary level care. The Human Research Ethics Committee of Austin Health approved the protocol and waived the need for informed consent (LNR/17/Austin/441). Study period was a convenience period with already retrieved data available.

\section{Participants}

We included all patients admitted to the Austin Hospital ICU during the study period. Only their first ICU admission was used for analysis. We excluded i) patients with an ICU stay < 24 hours, ii) known end-stage renal disease iii) patients admitted with increased first $\mathrm{Cr}$ values (females with first $\mathrm{Cr}$ over $90 \mu \mathrm{mol} / \mathrm{l}$ and male patients over $100 \mu \mathrm{mol} / \mathrm{l}$ ) and iv) patients with missing data on key variables (Figure 1). We only included patients with normal $\mathrm{Cr}$ values, because we aimed to study AKI developing in the ICU.

\section{Data sources}

We retrieved data regarding characteristics of the ICU admission from ICU Australian and New Zealand Intensive Care Society adult patient database (local version including patients treated at Austin Hospital ICU) and the ICU patient care computerized database, including data about ICU severity scores, interventions, and fluid therapy. These data were supplemented with the ICU blood gas analyser result database and hospital database regarding diagnostic coding. Point-ofcare measurement of $\mathrm{Cr}$ values (Radiometer ABL800 flex using non-isotope dilution mass spectrometry enzymatic assay and a two-electrode amperometric technique ${ }^{12}$ ) and their measurement time were included in the blood-gas analyser data. Patient outcome was followed up to hospital discharge from the hospital database.

Variables and definitions

From the point-of-care $\mathrm{Cr}$ database, we identified the following variables: i) the "first $\mathrm{Cr}^{\prime}$ ( $\left(\mathrm{Cr}_{\mathrm{F}}\right)$ measured within $2 \mathrm{~h}$ from ICU admission, ii) the "predictor $\mathrm{Cr}^{\prime}\left(\mathrm{Cr}_{\mathrm{p}}\right)$ measured at least 6 hours but 
no more than 12 hours from the first $\mathrm{Cr}$, and iii) the first $\mathrm{Cr}$ measured on Day $2\left(\mathrm{Cr}_{\text {DAY2 }}\right)$ at least 24 hours but no more than 48 hours from ICU admission.

We subtracted $\mathrm{Cr}_{\mathrm{P}}$ from the $\mathrm{Cr}_{F}$ and converted the difference into a percentage (delta-Cr-\%). The delta-Cr-\% was the primary exposure variable in the analysis.

\section{Outcomes}

The primary outcome was AKI on Day 2 based on $\mathrm{Cr}_{\text {DAY2 }}$ measurement and determined according to the Kidney Disease: Improving Global Outcomes (KDIGO) $\mathrm{Cr}$ and RRT criteria. ${ }^{7} \mathrm{Cr}_{\mathrm{F}}$ served as the baseline $\mathrm{Cr}^{13}$ as no data regarding outpatient $\mathrm{Cr}$ values preceding the index hospitalization were available. Data about urine output normalized to patient weight were unavailable which prevented the application of the KDIGO urine output criteria for AKI. We compared ICU and hospital length of stay and hospital mortality between patients with and without the primary endpoint.

Sample size

Analyses were performed on available patients and data on exposure and endpoint variables $(n=780)$ over a two-year period.

\section{Data analysis}

We constructed receiver operating characteristic $(R O C)$ curves and calculated the area under the curve (AUC) with $95 \%$ confidence intervals to evaluate the predictive ability of delta-Cr-\% for the primary endpoint in the entire cohort, among those who did not have AKI based on their $\mathrm{Cr}_{\mathrm{P}}$ measurement, and in groups according to admission category. We used Youden's index to derive optimal cut-points to calculate diagnostic characteristics with $95 \% \mathrm{Cls}$.

To study the value of delta-Cr-\% in addition of clinical risk variables as a predictor of AKI on day 2, we constructed two logistic regression models for AKI on Day 2; Model 1 with clinical risk variables and Model 2 with Model 1 variables and delta-Cr-\%. We considered baseline characteristics available at ICU admission (age, sex, admission type, diagnostic category), and details of ICU treatment available before the measurement of $\mathrm{Cr}_{\mathrm{p}}$ (use of mechanical ventilation, vasopressors, sedation, blood products, amount of administered intravenous fluids, urine output, 
and fluid balance), and additionally acute physiology and chronic health evaluation (APACHE) III score. The clinical predictors were first studied in univariate models and those with univariate Pvalue less than 0.2 and patient sex as recommended ${ }^{14}$ were considered further and a clinical risk model was constructed using forward stepwise regression. We assessed potential collinearity of variables with Pearson's correlation and excluded those with rho $>0.6$. Continuous variables regarding fluid input, output and balance were categorized in quartiles to improve model fit. We evaluated model fit with Hosmer-Lemeshow statistics.

Using the two models, we assessed the additional value of delta-Cr-\% in risk prediction with category-free net reclassification index (cfNRI) and integrated discrimination index (IDI). ${ }^{15}$ Category-free NRI describes the net improvement in predictive ability when a new risk factor is added to an existing model. IDI incorporates the direction and extent of change in the calculated risk. Additionally, we used DeLong's method to test for equality of the AUC's of the two prediction models. ${ }^{16}$ We repeated the analyses in a sub-cohort without patients who had AKI based on their $\mathrm{Cr}_{\mathrm{p}}$ measurement. Second, due to their varying risk profiles we performed subanalyses among only i) emergently admitted patients ii) cardiac surgical patients.

We report continuous data as medians with interquartile range and dichotomous data as count and percentage and main outcome variables with $95 \%$ confidence intervals. Missing data are indicated in the tables. We used Mann-Whitney U-test to compare continuous variables and Chi-Square or Fischer's exact test to compare categorical variables. We set the significance level at 0.05 and report two-tailed P-values. We conducted the analysis with SPSS statistics 24.0. for Mac (IBM, Armonk, NY) and RStudio 1.1.145 for Mac (RStudio Inc.)

\section{Results}

\section{Patients}

We studied 780 patients treated between 1.1.2011 and 31.12.2012. Figure 1 presents the patient flow and exclusions. Of the 780 patients, 343 (44.0\%) were admitted due to medical reasons, 212 (27.2\%) due to elective cardiovascular surgery, and 187 (24.0\%) were other surgical patients. Altogether 472 (60.5\%) were admitted emergently. 


\section{Index $\mathrm{Cr}$ values}

Median [IQR] $\mathrm{Cr}_{F}$ was 66 [54-79] $\mu \mathrm{mol} / \mathrm{l}$ and was recorded after a median [IQR] of 0.4 [0.2-0.9] hours from admission. Median [IQR] time between $\mathrm{Cr}_{F}$ and $\mathrm{Cr}_{p}$ was 8.2 [7.2-9.3] hours. The median [IQR] $\mathrm{Cr}_{p}$ was 71 [58-86] $\mu \mathrm{mol} / \mathrm{I}$. Overall, 70 (9.0\%) fulfilled the $\mathrm{Cr}$ AKI definition with their $\mathrm{Cr}_{\mathrm{p}}$ measurement; 62 (88.6\%) had stage 1, 6 (8.6\%) stage 2, and 2 (2.6\%) stage 3. Median [IQR] $\mathrm{Cr}_{\text {DAY2 }}$ was 71 [57-90] $\mu \mathrm{mol} / \mathrm{L}$ and it was measured after a median [IQR] of 25.4 [24.3-26.8] hours from ICU admission.

\section{Acute kidney injury on Day 2}

On day 2, 148 patients (19.0\%; 95\% Cl 16.2-21.7\%) were diagnosed with AKI. Stage 1 AKI was present in 117 (15.0\%), stage 2 in 19 (2.4\%) and stage 3 (including RRT) in 12 (1.5\%) patients. Altogether, seven patients commenced RRT before the $\mathrm{Cr}_{\mathrm{DAY} 2}$ measurement (five of them also fulfilling $\mathrm{Cr}$ AKI criteria based on $\left.\mathrm{Cr}_{\mathrm{DAY} 2}\right)$. On Day 2, of the 70 patients with AKI already diagnosed based on by $\mathrm{Cr}_{\mathrm{p}} 11$ (15.7\%) had resolved their AKI, 37 (52.95) had stage 1, 12 (17.1\%) stage 2, and $10(14.3 \%)$ stage 3 AKI.

Table 1 presents patient characteristics, ICU treatment, and length of ICU and hospital stay according to the presence of AKI on Day 2. Hospital mortality among patients with Day 2 AKI was 20 of 148 (13.5\%; 95\% Cl 8.0-19.0\%) compared to 55 of 631 (8.7\%; 95\% Cl 6.510.9\%) in those without $\mathrm{Cr} A K I$ at that time point, $\mathrm{P}=0.088$. Among the 472 emergently admitted patients, hospital mortality was 69 (14.6\%). Of those 68 emergently admitted with AKI 16 (23.5\%; 95\% $\mathrm{Cl}$ 13.4-33.6\%)) did not survive whereas 53 of 404 (13.1\%; 95\% Cl 9.8\%-16.4\%) non-AKI patients were non-survivors $(\mathrm{P}=0.024)$. Three $(1.4 \%)$ of 212 elective cardiac surgical patients did not survive hospitalization, 2 of whom had AKI.

\section{Delta-Cr-\% and prediction of AKI on Day 2}

In all patients, regardless of AKI diagnosed based on $\mathrm{Cr}_{p}$, the AUC of delta-Cr-\% for the development of Day 2 AKI was 0.82 (95\% $\mathrm{Cl} 0.78-0.86)$. After excluding patients who filled the $\mathrm{Cr}$ AKI diagnosis with their $\mathrm{Cr}_{\mathrm{P}}(\mathrm{n}=70), 89$ (12.5\%) of 710 patients had AKI based on $\mathrm{Cr}_{\text {DAY2 }}$. In these patients, the AUC for delta-Cr-\% to predict AKI on day 2 was 0.74 ( $95 \% \mathrm{Cl} 0.69-0.80$ ). Table 2 
presents cut-off values for delta-Cr-\% in the whole cohort and in the subgroups determined with Youden's index and the derived diagnostic parameters.

Table 3 presents the risk model for AKI on Day 2. The final model included patient sex, diagnostic category, APACHE III severity score as well as use of vasoactives or blood products within $6 \mathrm{hrs}$ of ICU admission. When delta-Cr-\% was added in the model, the performance improved significantly (Table 4). The result was robust to a sensitivity analysis excluding patients with AKI diagnosed with $\mathrm{Cr}_{p}(\mathrm{n}=70)$. The model with delta-Cr-\% performed well also among patients with emergency admission to ICU or elective cardiac surgery (Table 4). 


\section{Discussion}

Key findings

In a cohort of unselected patients admitted to a general ICU, almost one in five developed AKI by the following day. Change in point-of-care $\mathrm{Cr}$ from ICU admission to approximately 8 hours after admission predicted subsequent AKI development the following day with an AUC of 0.82. Adding the delta-Cr-\% to a clinical risk model markedly improved the predictive ability of the model. The results were robust to exclusion of those patients who had already developed AKI by the time of measurement of the $\mathrm{Cr}_{p}$ value and remained essentially unchanged in subgroups of emergently admitted patients and elective cardiac surgical patients.

\section{Relationship to previous literature}

Our results corroborate those from cohort studies among cardiac surgical patients that have reported that small, early changes of $\mathrm{Cr}$ perform well in predicting subsequent AKI.8, 17 Our results markedly expand these observations as our cohort was a mixed critically ill patient cohort. The AUC of delta-Cr-\% for predicting AKI on the following day was 0.82 ( 0.74 if patients classified as having AKI based on the $\mathrm{Cr}_{\mathrm{p}}$ are excluded), which is similar to that of many novel urine or plasma biomarkers and clinical prediction models, especially in undifferentiated mixed populations of ICU patients. ${ }^{5}$ Moreover, adding the delta-Cr-\% to a clinical risk model predicting AKI improved the predictive power of the model significantly, with cfNRI of $90 \%$ and IDI 0.20 . For comparison, adding IGFB-7 * TIMP-2 to a clinical risk model yielded an cfNRI of $70 \%$ and IDI 0.098 .18 We found a sensitivity of $71.6 \%$ and a specificity of $79.4 \%$ for the cutoff of $17.1 \%$ for Day $2 \mathrm{AKI}$, also within reasonable limits for diagnostic purposes.

In approximately $40 \%$ of the patients with AKI on Day 2, the Cr-based diagnosis could be made much earlier using the $\mathrm{Cr}$ value obtained about $8 \mathrm{hrs}$ from ICU admission. A recent prospective analysis found that $\mathrm{Cr}$ measured only 3-4 hours from ICU admission was also a sensitive predictor of subsequent AKI. ${ }^{9}$ Together these findings support the role of more frequent monitoring of $\mathrm{Cr}$ to achieve an earlier diagnosis of developing AKI.

Time to reach $\mathrm{AKI}$ diagnosis based on percentage increases in $\mathrm{Cr}$ is highly dependent on the baseline $\mathrm{Cr} .{ }^{19}$ Patients with normal baseline kidney function reached diagnosis of AKI based on percentage or absolute increase in $\mathrm{Cr}$ fast, even within a few hours, depending 
on the severity of insult in a simulation study. ${ }^{20}$ These findings were validated in a cohort of cardiac surgical patients. ${ }^{21}$ Our results among patients with normal baseline kidney function corroborate these findings.

\section{Clinical implications}

Our findings imply that measuring $\mathrm{Cr}$ more frequently using point-of-care technology could help to predict AKI occurring the next day. Its performance in predicting AKI was similar or better than many novel biomarkers. ${ }^{5}$ Given that $\mathrm{Cr}$ is an easily available and inexpensive laboratory test, our findings also imply that the comparative utility of point-of-care $\mathrm{Cr}$ measurements in predicting AKI in a heterogeneous critically ill population should be tested in prospective multicenter cohorts.

\section{Strengths and limitations}

The strengths of our analysis include a unique database with routine frequent point-of-care measured $\mathrm{Cr}$ values from a large cohort of patients. Moreover, patients were not selected but rather represented a heterogeneous group of ICU patient as are admitted every day where the issue of early diagnosis arises. In addition, delta-Cr-\% performed well in subgroups of emergency admissions and elective cardiac surgical patients strengthening our findings. Our results were robust to different assessment methodologies providing evidence of their reliability. Finally, by showing that simply measuring $\mathrm{Cr}$ more frequently (a very low-cost test) may be as good as more expensive approaches with novel biomarkers, it provides a novel, simple and inexpensive comparator against which future biomarker studies would have to be tested.

This analysis, however, has some limitations. It was a retrospective database audit from a single center, and thus, has all the inherent limitations of such an approach. In the critically ill, several confounders affecting Cr-based AKI definitions have been identified. These include volume overload and subsequent dilution of $\mathrm{Cr},{ }^{22}$ malnutrition, and muscle wasting. ${ }^{13} \mathrm{We}$ did not find difference in cumulative fluid balances among patients with and without AKI in the first 6 hours, and thus, the $\mathrm{Cr}_{\mathrm{p}}$ value is unlikely to be affected by fluid balance. ${ }^{23}$ Significant muscle wasting and malnutrition are unlikely to have occurred within the first 24 hours of intensive care. The incidence of AKI in our cohort was slightly lower than in other reports ${ }^{1,2}$ likely 
because we excluded patients with increased $\mathrm{Cr}$ on ICU admission. This exclusion also led us to study a cohort that had predominantly stage $1 \mathrm{AKI}$ and an overall low hospital mortality rate.

No true baseline $\mathrm{Cr}^{7}$ was available, and we used the $\mathrm{Cr}_{\mathrm{F}}$ instead. This may have led to underestimation of $\mathrm{AKI}$ incidence. ${ }^{24}$ On the other hand, we restricted analysis to those admitted to ICU with apparently normal $\mathrm{Cr}$ to minimize this bias. Furthermore, we did not have sufficient data to assess urine output criteria. Thus, the AKI incidence might have been higher than reported, and the predictive ability of delta-Cr-\% less than observed. Additionally, the diagnosis of AKI might have been evident based on urine output before a rise in $\mathrm{Cr}$ was detected. ${ }^{25}$ However, as such measurement were performed on average within 8 hours and very few patients would have sufficient time to reach the urinary output criteria for KDIGO AKI before such second measurement. Finally, we collected routine data from the databases and could not adjust for many known risk factors for AKI, such as drugs harmful to the kidneys, which might have improved the performance of a clinical risk model without delta-Cr-\% and allowed us to use some of the pre-existing risk models. ${ }^{26}$ Despite these limitations, the predictive ability of delta$\mathrm{Cr}-\%$ appeared very promising and worth investigating in future prospective studies.

\section{Conclusions}

Small increases in point-of-care $\mathrm{Cr}$ values developing rapidly after ICU admission were frequent among critically ill patients admitted with normal $\mathrm{Cr}$ values. The delta-Cr-\% from ICU admission value to a value measured approximately 8 hours from admission performed well in predicting subsequent $\mathrm{AKI}$ on the following day. More frequent measurement of $\mathrm{Cr}$ by point-of-care may be a simple, inexpensive and easy to perform predictive test and represent a performance benchmark for future biomarker studies.

\section{Acknowledgements}

STV has received a Fellowship Grant from the Sigrid Juselius Foundation and funding for Clinical Researchers (317061) from the Academy of Finland.

The authors declare no conflicts of interest. 
Figure 1: Flow chart

AKI; acute kidney injury, Cr; creatinine, ESRD; end-stage renal disease, ICU; intensive care unit, LOS; length of stay, RRT; renal replacement therapy

This article is protected by copyright. All rights reserved 
Table 1. Characteristics of all patients and compared according to presence of acute kidney injury on Day 2.

\begin{tabular}{|c|c|c|c|c|}
\hline & All patients & AKI on Day 2 & No AKI on day 2 & $\begin{array}{l}P \text { - } \\
\text { value }\end{array}$ \\
\hline No of patients & 780 & 148 & 632 & \\
\hline Delta Cr umol/L & $5.0[-2.0-13.0]$ & $19.0[8.3-30.0]$ & $3.0[-3.0-9.0]$ & $<0.001$ \\
\hline Delta \% & $8.5[-2.5-20.4]$ & $27.8[13.6-41.6]$ & $5.6[-4.2-14.8]$ & $<0.001$ \\
\hline Age -years & $63.0[48.9-73.0]$ & $66.7[54.8-78.0]$ & $62.5[47.3-71.5]$ & 0.001 \\
\hline Male Sex & $478 / 780(61.3 \%)$ & $84 / 148(56.8 \%)$ & $394 / 632(62.3 \%)$ & 0.223 \\
\hline Operative admission & 437/772 (56.0\%) & 105/148 (70.9\%) & $332 / 632$ (52.5\%) & $<0.001$ \\
\hline Emergency admission & $473 / 780(60.6 \%)$ & 68/148 (45.9\%) & 405/632 (64.1\%) & $<0.001$ \\
\hline Elective cardiac surgery & $212 / 780(27.2 \%)$ & $62 / 148(41.9 \%)$ & $150 / 632(23.7 \%)$ & $<0.001$ \\
\hline \multicolumn{5}{|l|}{ Admitted from } \\
\hline Emergency department & $146(18.7 \%)$ & $16 / 148(10.8 \%)$ & $130 / 632(20.6 \%)$ & 0.005 \\
\hline Operating room & $438(56.2 \%)$ & $105 / 148(70.9 \%)$ & $333 / 632$ (52.7\%) & $<0.001$ \\
\hline Ward & $176(22.6 \%)$ & $27 / 148(18.2 \%)$ & $149 / 632(23.6 \%)$ & 0.190 \\
\hline Other ICU & $20(2.6 \%)$ & $0 / 148(0 \%)$ & $20 / 632(3.2 \%)$ & 0.020 \\
\hline \multicolumn{5}{|l|}{ Within $6 \mathrm{hrs}$} \\
\hline On mechanical ventilation & $608 / 780(77.9 \%)$ & $125 / 148(84.5 \%)$ & $483 / 632$ (76.4\%) & 0.036 \\
\hline Received vasopressors & $393 / 780$ (50.4\%) & $98 / 148(66.2 \%)$ & 295/632 (46.7\%) & $<0.001$ \\
\hline Received sedation & $583 / 780(50.4 \%)$ & $115 / 148(77.7 \%)$ & $468 / 632$ (74.1\%) & 0.401 \\
\hline Received blood products & $116 / 780(14.9 \%)$ & $42 / 148(28.4 \%)$ & 74/632 (11.7\%) & $<0.001$ \\
\hline $\begin{array}{l}\text { Total amount of iv fluids - } \\
\mathrm{mL}\end{array}$ & 743.0 [294.5-1683.8] & $973.0[343.0-2084.3]$ & $702.0[278.5-1582.5]$ & 0.026 \\
\hline $\begin{array}{l}\text { Cumulative urine output - } \\
\mathrm{mL}\end{array}$ & 770 [420.0-1409.5] & 747.5 [416.3-1435.0] & 770.0 [420.0-1383.8] & 0.923 \\
\hline Fluid balance-mL & $-181.5[-706.5-521.3]$ & $-38.5[-707.0-716.3]$ & $-205.0[-704.8-441.3]$ & 0.210 \\
\hline \multicolumn{5}{|l|}{ Within $24 \mathrm{hrs}$} \\
\hline On mechanical ventilation & $622 / 780(79.7 \%)$ & $129 / 148(87.2 \%)$ & $493 / 632(78.0 \%)$ & 0.012 \\
\hline Received vasopressors & $509 / 780(65.3 \%)$ & $119 / 148(80.4 \%)$ & $390 / 632$ (61.7\%) & $<0.001$ \\
\hline Received sedation & $633 / 779(81.3 \%)$ & $129 / 148(87.2 \%)$ & $504 / 631$ (79.9\%) & 0.046 \\
\hline Received blood products & $180 / 780(23.1 \%)$ & $61 / 148(41.2 \%)$ & $119 / 632$ (18.8\%) & $<0.001$ \\
\hline $\begin{array}{l}\text { Total amount of iv fluids - } \\
\mathrm{mL}\end{array}$ & $\begin{array}{l}2842.0[2014.0- \\
4056.0]\end{array}$ & $\begin{array}{l}3116.0[2086.8- \\
4331.3]\end{array}$ & $\begin{array}{l}2808.0[1974.0- \\
3987.0]\end{array}$ & 0.092 \\
\hline
\end{tabular}

This article is protected by copyright. All rights reserved 


\begin{tabular}{|l|l|l|l|l|}
\hline Cumulative urine output - & $\begin{array}{l}2147.5[1557.8- \\
\mathrm{mL}\end{array}$ & $\begin{array}{l}1775.5[1178.5- \\
2939.0]\end{array}$ & $\begin{array}{l}2197.0[1634.0- \\
2992.3]\end{array}$ & $<0.001$ \\
\hline Fluid balance $-\mathrm{mL}$ & $317.0[-730.0-1475.0]$ & $619.0[-313.3-1684.5]$ & $219.0[-853.0-1379.0]$ & 0.002 \\
\hline APACHE III score & $53[41-67]$ & $58.5[48.3-71.8]$ & $52.0[39.0-67.0]$ & $<0.001$ \\
\hline $\begin{array}{l}\text { ICU length of stay -days } \\
\text { Hospital length of stay -days }\end{array}$ & $2.8[1.9-4.7]$ & $3.06[2.0-6.0]$ & $2.7[1.9-4.6]$ & 0.001 \\
\hline
\end{tabular}

Continuous data presented as median [interquartile range] and categorical as count and percentage.

AKI; acute kidney injury

APACHE; Acute Physiology and Chronic Health Evaluation

$\mathrm{Cr}$; Creatinine

ICU; Intensive Care Unit 
Table 2. Diagnostic parameters of delta-creatinine-percentage to predict acute kidney injury on

Day 2.

\begin{tabular}{|c|c|c|c|c|c|c|}
\hline Patient group (n) & $\begin{array}{l}\text { AKI on Day } \\
2-n(\%)\end{array}$ & Sensitivity & Specificity & $A \cup C$ & $\begin{array}{l}\text { Cut-off } \\
\%\end{array}$ & $\begin{array}{l}\text { Positive } \\
\text { likelihood ratio }\end{array}$ \\
\hline All patients (780) & $148(19.0)$ & $\begin{array}{l}71.6 \\
(63.3-78.7)\end{array}$ & $\begin{array}{l}79.4 \\
(76.0-82.5)\end{array}$ & $\begin{array}{l}0.822 \\
(0.782-0.863)\end{array}$ & 17.1 & $3.5(2.9-4.2)$ \\
\hline $\begin{array}{l}\text { AKI positive with } \\
\text { predictor } \mathrm{Cr} \\
\text { excluded (710) }\end{array}$ & $89(12.5)$ & $\begin{array}{l}78.7 \\
(68.7-86.6)\end{array}$ & $\begin{array}{l}62.5 \\
(58.5-66.3)\end{array}$ & $\begin{array}{l}0.744 \\
(0.687-0.800)\end{array}$ & 9.2 & $2.1(1.8-2.4)$ \\
\hline $\begin{array}{l}\text { Emergency } \\
\text { admission (473) }\end{array}$ & $68(14.4)$ & $\begin{array}{l}75.0(0.63 .0- \\
84.7)\end{array}$ & $\begin{array}{l}76.3(71.8- \\
80.4)\end{array}$ & $\begin{array}{l}0.815(0.755- \\
0.875)\end{array}$ & 11.1 & $3.16(2.53-3.95)$ \\
\hline $\begin{array}{l}\text { Elective cardiac } \\
\text { surgery (212) }\end{array}$ & $62(29.2)$ & $\begin{array}{l}64.5 \text { (51.3- } \\
76.3)\end{array}$ & $\begin{array}{l}82.7 \text { (75.6- } \\
88.4)\end{array}$ & $\begin{array}{l}0.801(0.734- \\
0.867)\end{array}$ & 23.4 & $3.7(2.5-5.5)$ \\
\hline
\end{tabular}

Numbers in parenthesis indicate $95 \%$ confidence intervals.

AKI; acute kidney injury

AUC; area under the curve

This article is protected by copyright. All rights reserved 
Table 3. Construction of the risk model for acute kidney injury on Day 2.

\begin{tabular}{|c|c|c|c|c|}
\hline Covariate* & $\begin{array}{l}\text { Univariate odds } \\
\text { ratio }(95 \% \mathrm{Cl})\end{array}$ & P-value & $\begin{array}{l}\text { Multivariable Model } 1 \text { odds } \\
\text { ratio }(95 \% \mathrm{Cl})^{* *}\end{array}$ & $\begin{array}{l}\text { P- } \\
\text { value }\end{array}$ \\
\hline Age & $1.02(1.01-1.03)$ & $<0.001$ & & \\
\hline Male Sex & $0.79(0.55-1.14)$ & 0.210 & $0.68(0.46-0.997)$ & 0.048 \\
\hline Operative admission & $2.21(1.50-3.25)$ & $<0.001$ & & \\
\hline Emergency admission & $0.48(0.33-0.68)$ & $<0.001 * * *$ & & \\
\hline Diagnostic category & $0.90(0.84-0.95)$ & $<0.001$ & $0.90(0.85-0.95)$ & $<0.001$ \\
\hline APACHE III score & $1.01(1.00-1.02)$ & 0.006 & $1.02(1.01-1.03)$ & $<0.001$ \\
\hline $\begin{array}{l}\text { On mechanical ventilation } \\
\text { within } 6 \text { hrs }\end{array}$ & $1.68(1.04-2.71)$ & 0.035 & & \\
\hline $\begin{array}{l}\text { Received vasopressors } \\
\text { within } 6 \mathrm{hrs}\end{array}$ & $2.24(1.54-3.26)$ & $<0.001$ & $1.70(1.14-2.53)$ & 0.009 \\
\hline $\begin{array}{l}\text { Received sedation within } 6 \\
\text { hrs }\end{array}$ & $1.22(0.80-1.87)$ & 0.358 & & \\
\hline $\begin{array}{l}\text { Received blood products } \\
\text { within } 6 \mathrm{hrs}\end{array}$ & $2.99(1.94-4.60)$ & $<0.001$ & $2.33(1.49-3.67)$ & $<0.001$ \\
\hline $\begin{array}{l}\text { Total amount of iv fluids } \\
\text { within } 6 \text { hrs }\end{array}$ & & & & \\
\hline $1^{\text {st }}$ quartile $(<295 \mathrm{~mL})$ & reference & & & \\
\hline $2^{\text {nd }}$ quartile $\left.(295-743 \mathrm{~mL})\right)$ & $1.11(0.65-1.91)$ & 0.696 & & \\
\hline $3^{\text {rd }}$ quartile $(744-1684 \mathrm{~mL})$ & $1.25(0.74-2.13)$ & 0.405 & & \\
\hline $4^{\text {th }}$ quartile (>1684mL) & $1.85(1.11-3.06)$ & 0.018 & & \\
\hline $\begin{array}{l}\text { Cumulative urine output } \\
\text { quartile within } 6 \mathrm{~h}\end{array}$ & & & & \\
\hline $4^{\text {th }}$ quartile (>1410mL) & reference & & & \\
\hline $3^{\text {rd }}$ quartile $(771-1410 \mathrm{~mL})$ & $0.72(0.43-1.20)$ & 0.206 & & \\
\hline $2^{\text {nd }}$ quartile $(421-770 \mathrm{~mL})$ & $0.83(0.51-1.37)$ & 0.463 & & \\
\hline $1^{\text {st }}$ quartile $(<420 \mathrm{~mL})$ & $0.87(0.53-1.42)$ & 0.581 & & \\
\hline Fluid balance quartile & & & & \\
\hline
\end{tabular}

This article is protected by copyright. All rights reserved 


\begin{tabular}{|l|l|l|l|}
\hline within $6 \mathrm{hrs}$ & & & \\
\hline $1^{\text {st }}$ quartile $(<-707 \mathrm{~mL})$ & reference & & \\
\hline $2^{\text {nd }}$ quartile $(-707--182 \mathrm{~mL})$ & $0.69(0.41-1.18)$ & 0.178 & \\
\hline $3^{\text {rd }}$ quartile $(-183-521 \mathrm{~mL})$ & $1.03(0.63-1.70)$ & 0.899 & \\
\hline $4^{\text {th }}$ quartile $(>521 \mathrm{~mL})$ & $1.17(0.72-1.91)$ & 0.533 & \\
\hline Delta Creatinine $\%$ & $1.07(1.06-1.09)$ & $<0.001$ & \\
\hline
\end{tabular}

*Bolded covariates were entered in a multivariable forward stepwise logistic regression model.

** The variables remaining in the final model. Hosmer-Lemeshow chi-square 6.309, $p=0.613$

Model area-under-the curve $(95 \% \mathrm{Cl})$ for AKI on day $20.69(0.65-0.74)$

*** excluded from the risk model due to collinearity with operative admission

APACHE; acute physiology and chronic health evaluation 
Table 4. Performance of the risk model for Day 2 acute kidney injury with and without delta-Crpercentage.

\begin{tabular}{|c|c|c|c|c|c|c|c|c|c|}
\hline & $\begin{array}{l}\mathrm{N} \\
\text { total }\end{array}$ & $\begin{array}{l}\mathrm{N} \\
\text { events }\end{array}$ & $\begin{array}{l}\text { Model } 1 \\
\text { goodness } \\
\text { of fit }\end{array}$ & $\begin{array}{l}\text { Model } \\
1 \text { AUC } \\
(95 \% \\
\text { Cl) }\end{array}$ & $\begin{array}{l}\text { Model } 2 \\
\text { goodness } \\
\text { of fit }\end{array}$ & $\begin{array}{l}\text { Model } \\
2 \text { AUC } \\
(95 \% \mathrm{Cl})\end{array}$ & $\begin{array}{l}\text { P-value for } \\
\text { comparison } \\
\text { of AUCs }\end{array}$ & $\begin{array}{l}\text { Category- } \\
\text { free NRI } \\
(\%)\end{array}$ & IDI \\
\hline All patients & 780 & 148 & $\begin{array}{l}6.15, \\
p=0.63\end{array}$ & $\begin{array}{l}0.70 \\
(0.65- \\
0.74)\end{array}$ & $\begin{array}{l}6.19 \\
p=0.63\end{array}$ & $\begin{array}{l}0.83 \\
(0.79- \\
0.87)\end{array}$ & $<0.001$ & $\begin{array}{l}90.0 \\
(74.9- \\
106.1)\end{array}$ & $\begin{array}{l}0.20 \\
(0.16- \\
0.24)\end{array}$ \\
\hline $\begin{array}{l}\text { AKI } \\
\text { positive } \\
\text { with } \\
\text { predictor } \\
\mathrm{Cr} \\
\text { excluded }\end{array}$ & 710 & 89 & $\begin{array}{l}\text { 4.51, } \\
p=0.808\end{array}$ & $\begin{array}{l}0.67 \\
(0.61- \\
0.73)\end{array}$ & $\begin{array}{l}8.26 \\
p=0.408\end{array}$ & $\begin{array}{l}0.76 \\
(0.71- \\
0.81)\end{array}$ & 0.002 & $\begin{array}{l}64.3 \\
(43.3- \\
85.2)\end{array}$ & $\begin{array}{l}0.06 \\
(0.04- \\
0.09)\end{array}$ \\
\hline $\begin{array}{l}\text { Emergency } \\
\text { admissions }\end{array}$ & 473 & 68 & $\begin{array}{l}7.68 \\
p=0.465\end{array}$ & $\begin{array}{l}0.69 \\
(0.63- \\
0.76)\end{array}$ & $\begin{array}{l}7.65 \\
p=0.468\end{array}$ & $\begin{array}{l}0.84 \\
(0.79- \\
0.90)\end{array}$ & $<0.001$ & $\begin{array}{l}101.6 \\
(79.4- \\
123.8)\end{array}$ & $\begin{array}{l}0.20 \\
(0.14- \\
0.27)\end{array}$ \\
\hline $\begin{array}{l}\text { Elective } \\
\text { cardiac } \\
\text { surgical } \\
\text { patients }\end{array}$ & 212 & 62 & $\begin{array}{l}3.86 \\
p=0.870\end{array}$ & $\begin{array}{l}0.70 \\
(0.63- \\
0.78)\end{array}$ & $\begin{array}{l}4.43 \\
p=0.817\end{array}$ & $\begin{array}{l}0.82 \\
(0.76- \\
0.88)\end{array}$ & $<0.001$ & $\begin{array}{l}75.5 \\
(48.0- \\
103.0)\end{array}$ & $\begin{array}{l}0.20 \\
(0.14- \\
0.26)\end{array}$ \\
\hline
\end{tabular}

Numbers in parenthesis indicate 95\% confidence intervals. Goodness-of-fit assessed with HosmerLemeshow test.

Model 1; risk model for AKI without delta $\mathrm{Cr}$

Model 2; risk model for AKI with delta-Cr

Risk model includes: patient sex, APACHE II diagnostic group, APACHE III score, need for vasoctives (within $6 \mathrm{hrs}$ of ICU admission) and need for blood products (within $6 \mathrm{hrs}$ of ICU admission).

APACHE; acute physiology and chronic health evaluation

AUC; area under the curve

$\mathrm{NRI}$; net reclassification index

IDI; integrated discrimination index

This article is protected by copyright. All rights reserved 


\section{References}

1.

Nisula S, Kaukonen KM, Vaara ST, Korhonen AM, Poukkanen M, Karlsson S, et al. Incidence, risk factors and 90-day mortality of patients with acute kidney injury in Finnish intensive care units: the FINNAKI study. Intensive Care Med. 2013;39:420-8.

Hoste EA, Bagshaw SM, Bellomo R, Cely CM, Colman R, Cruz DN, et al. Epidemiology of acute kidney injury in critically ill patients: the multinational AKI-EPI study. Intensive Care Med. 2015;41:1411-23.

3. Griffin BR, Gist KM, Faubel S. Current Status of Novel Biomarkers for the Diagnosis of Acute Kidney Injury: A Historical Perspective. J Intensive Care Med. 2019:885066618824531. 4. Malhotra R, Siew ED. Biomarkers for the Early Detection and Prognosis of Acute Kidney Injury. Clin J Am Soc Nephrol. 2017;12:149-73.

5.

Pozzoli S, Simonini M, Manunta P. Predicting acute kidney injury: current status and future challenges. J Nephrol. 2018;31:209-23.

6. Kellum JA, Sileanu FE, Murugan R, Lucko N, Shaw AD, Clermont G. Classifying AKI by Urine Output versus Serum Creatinine Level. J Am Soc Nephrol. 2015;26:2231-8.

7. Kidney Disease: Improving Global Outcomes (KDIGO) Acute Kidney Injury Work Group. KDIGO Clinical Practice Guideline for Acute Kidney Injury. Kidney Int Suppl. 2012:1- 138. 8. Ho J, Reslerova M, Gali B, Nickerson PW, Rush DN, Sood MM, et al. Serum creatinine measurement immediately after cardiac surgery and prediction of acute kidney injury. Am J Kidney Dis. 2012;59:196-201.

9. Toh L, Bitker L, Eastwood GM, Bellomo R. The incidence, characteristics, outcomes and associations of small short-term point-of-care creatinine increases in critically ill patients. J Crit Care. 2019;52:227-32.

10. Calzavacca P, Tee A, Licari E, Schneider AG, Bellomo R. Point-of-care measurement of serum creatinine in the intensive care unit. Ren Fail. 2012;34:13-8.

11. Udy A, O'Donoghue S, D'Intini V, Healy H, Lipman J. Point of care measurement of plasma creatinine in critically ill patients with acute kidney injury. Anaesthesia. 2009;64:403-7. 12. Radiometer. ABL800 FLEX reference manual. . Denmark. : Radiometer Medical ApS; 2008. 
13. De Rosa S, Samoni S, Ronco C. Creatinine-based definitions: from baseline creatinine to serum creatinine adjustment in intensive care. Crit Care. 2016;20:69.

14.

Leslie K, Kasza J. Sex and gender inclusion, analysis, and reporting in anaesthesia research. Br J Anaesth. 2020. doi: 10.1016/j.bja.2019.12.003.

15.

Pencina MJ, D'Agostino RB, Sr., Steyerberg EW. Extensions of net reclassification improvement calculations to measure usefulness of new biomarkers. Stat Med. 2011;30:11-21. 16. DeLong ER, DeLong DM, Clarke-Pearson DL. Comparing the areas under two or more correlated receiver operating characteristic curves: a nonparametric approach. Biometrics. 1988;44:837-45.

17. Karkouti K, Rao V, Chan CT, Wijeysundera DN. Early rise in postoperative creatinine for identification of acute kidney injury after cardiac surgery. Can J Anaesth. 2017;64:801-9. 18. Kashani K, Al-Khafaji A, Ardiles T, Artigas A, Bagshaw SM, Bell M, et al. Discovery and validation of cell cycle arrest biomarkers in human acute kidney injury. Crit Care. 2013;17:R25

19. Waikar SS, Bonventre JV. Creatinine kinetics and the definition of acute kidney injury. J Am Soc Nephrol 2009;20:672-9.

20. James MT, Wald R, Bell CM, Tonelli M, Hemmelgarn BR, Waikar SS, et al. Weekend hospital admission, acute kidney injury, and mortality. J Am Soc Nephrol 2010;21:845-51.

21. Garrido JM, Candela-Toha AM, Parise-Roux D, Tenorio M, Abraira V, Del Rey JM, et al. Impact of a new definition of acute kidney injury based on creatinine kinetics in cardiac surgery patients: a comparison with the RIFLE classification. Interact Cardiovasc Thorac Surg. 2015;20:338-44.

22.

Liu KD, Thompson BT, Ancukiewicz M, Steingrub JS, Douglas IS, Matthay MA, et al. Acute kidney injury in patients with acute lung injury: impact of fluid accumulation on classification of acute kidney injury and associated outcomes. Crit Care Med. 2011;39:2665-71. 23. Prowle JR, Leitch A, Kirwan CJ, Forni LG. Positive fluid balance and AKI diagnosis: assessing the extent and duration of 'creatinine dilution'. Intensive Care Med. 2015;41:160-1. 24. Siew ED MM, Ikizler TA, Lewis JB, Miller RA, Waitman LR, Go AS, Parikh CR, Peterson JF. Commonly used surrogates for baseline renal function affect the classification and prognosis of acute kidney injury. Kidney Int. 2010;77:536-42. 
25. Vaara ST, Parviainen I, Pettilä V, Nisula S, Inkinen O, Uusaro A. Association of oliguria with the development of acute kidney injury in the critically ill. Kidney Int. 2016;89:2008.

26.

Neyra JA, Leaf DE. Risk Prediction Models for Acute Kidney Injury in Critically III Patients: Opus in Progressu. Nephron. 2018;140:99-104. 


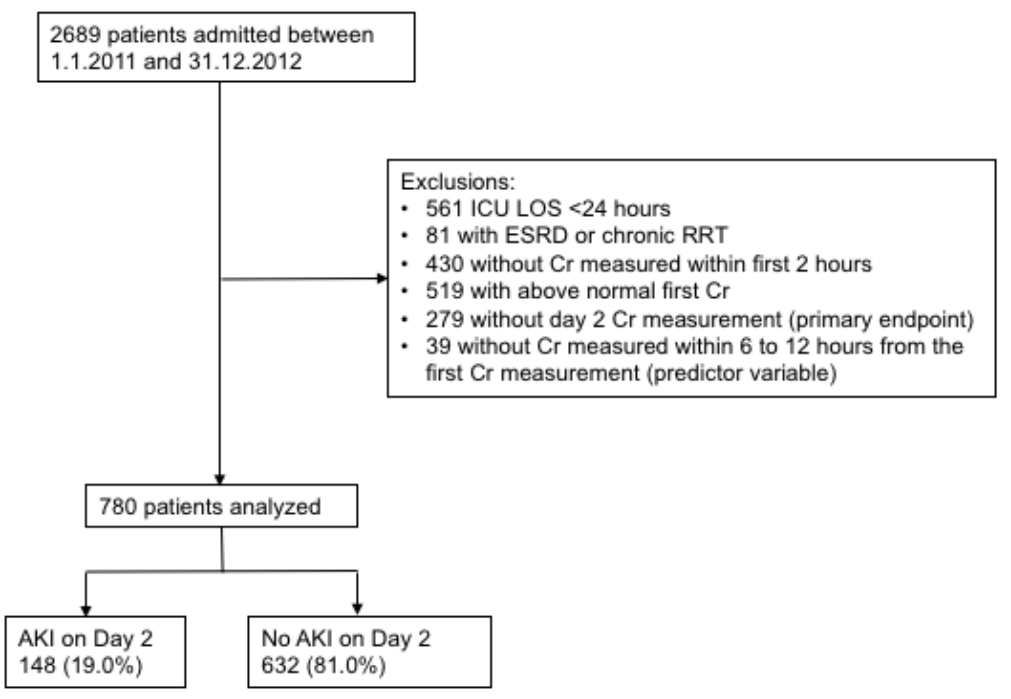

aas_13564_f1.tiff

This article is protected by copyright. All rights reserved 